\title{
0 ensino religioso e a prática pedagógica em uma escola na Amazônia Marajoara
}

\author{
Recebido em 15/05/2020, aprovado em 12/08/2020 \\ DOI: $10.30612 / m v t . v 7 i 12.11939$ \\ Jefeson da Silva Souza' \\ Sônia Maria Pereira do Amaral²
}

\begin{abstract}
RESUMO: O presente artigo tem como objetivo discutir o Ensino Religioso - ER e a prática pedagógica em uma escola municipal na Amazônia marajoara. Trata-se de um recorte do resultado de pesquisa elaborada como atividade de Trabalho de Conclusão de Curso - Licenciatura em Pedagogia na UFPA - Campus Universitário do Marajó - Breves. A pesquisa utilizou-se da abordagem qualitativa, por meio de um estudo de caso em uma escola de ensino fundamental, tendo como objetivos: verificar se o currículo adotado pela escola contribui com o respeito e a aceitação das religiôes existentes na sociedade; Identificar se as práticas pedagógicas desenvolvidas pelos professores contribuem para fomentar o respeito e combater a intolerância religiosa em sala de aula e discutir a importância do ER na promoção do respeito e na valorização do ser humano. Para análises dos dados buscou-se fazer os debates sobre o ER na perspectiva de autores como: Custódio (2017, 2016, 2015), Junqueira (2017) e Holanda (2017). Os resultados da pesquisa apontaram que a prática pedagógica do ER, neste período, oscilava entre um ensino crítico e libertador e um ensino que se aproximava à doutrinação, ao proselitismo. Promovia o respeito e a tolerância, religiosa, de gênero, e racial em sala de aula. Entretanto, na dicotomia de concepçôes, não se pode afirmar, se o que os alunos e alunas levarão para a vida social, serão as aprendizagens que valorizam a vida humana, ou a influência dos fortes discursos religiosos que se apresentavam no decorrer das aulas.
\end{abstract}

Palavras-chave: Ensino Religioso. Currículo. Prática Pedagógica.

\section{Religious teaching and pedagogical practice in a school in the Amazonia Marajoara}

ABSTRACT: This article aims to discuss Religious Education - ER and pedagogical practice in a municipal school in the Amazon of Maranhão. This is an excerpt from the research result elaborated as a Course Completion Work activity - Degree in Pedagogy at UFPA - Campus Universitário do Marajó - Breves. The research used the qualitative approach, through a case study in an elementary

\footnotetext{
$1 \quad$ Licenciado em Pedagogia pela Universidade Federal do Pará - UFPA. jhefesonsilva@hotmail.com

2 Pedagoga, Doutora em Antropologia pelo PPGA-UFPA. Professora da UFPA/Campus Universitário do Marajó-Breves, com atuação na Faculdade de Educação e Ciências Humanas, ministrando as disciplinas Antropologia Educacional, Práticas Pedagógicas e orientadora de Estágios Supervisionados na Educaçáo básica. smpa40@yahoo.com.br
} 
school, with the following objectives: Check if the curriculum adopted by the school contributes to the respect and acceptance of existing religions in society; Identify whether the pedagogical practices developed by teachers contribute to foster respect and combat religious intolerance in the classroom and discuss the importance of RE in promoting respect and valuing human beings. For data analysis, we sought to make debates about RE from the perspective of authors such as: Custódio (2017, 2016, 2015), Junqueira (2017) and Holanda (2017). The results of the research showed that the pedagogical practice of ER, in this period, oscillated between a critical and liberating teaching and a teaching that was close to indoctrination, proselytism. It promoted respect and tolerance, religious, gender, and racial in the classroom. However, in the dichotomy of conceptions, it cannot be said, whether what the students will take to social life, will be the learning that values human life, or the influence of strong religious discourses that were presented during the classes.

Keywords: Religious education. Curriculum. Pedagocical Practice.

\section{Enseñanza religiosa y práctica pedagógica en una escuela en Amazonia Marajoara}

RESUMEN: Este artículo tiene como objetivo discutir la Educación Religiosa - ER y la práctica pedagógica en una escuela municipal en la Amazonía de Marajó. Este es un extracto del resultado de la investigación elaborado como una actividad de trabajo de finalización del curso - Licenciatura en Pedagogía en UFPA - Campus Universitário do Marajó - Breves. La investigación utilizó el enfoque cualitativo, a través de un estudio de caso en una escuela primaria, con los siguientes objetivos: Verificar si el plan de estudios adoptado por la escuela contribuye al respeto y la aceptación de las religiones existentes en la sociedad; Identificar si las prácticas pedagógicas desarrolladas por los maestros contribuyen a fomentar el respeto y combatir la intolerancia religiosa en el aula y discutir la importancia de la ER en la promoción del respeto y la valoración de los seres humanos. Para el análisis de datos, buscamos debatir sobre ER desde la perspectiva de autores como: Custódio (2017, 2016, 2015), Junqueira (2017) y Holanda (2017). Los resultados de la investigación mostraron que la práctica pedagógica de ER, en este período, oscilaba entre una enseñanza crítica y liberadora y una enseńanza cercana al adoctrinamiento, al proselitismo. Promovió el respeto y la tolerancia, religiosa, de género y racial en el aula. Sin embargo, en la dicotomía de las concepciones, no se puede decir si lo que los estudiantes llevarán a la vida social será el aprendizaje que valora la vida humana o la influencia de los fuertes discursos religiosos que se presentaron durante las clases.

Palavras Clave: Educación religiosa. Plan de estúdios. Práctica pedagógica.

\section{INTRODUÇÃO}

Por constar no currículo formal das escolas públicas e pela laicidade do Estado brasileiro, o Ensino Religioso - ER gera muitos debates quanto ao seu caráter facultativo, em muitos momentos proselitista no que concerne aos seus conteúdos curriculares, ou seja, a questão está em que modelo de ER deve ser adotado nas escolas públicas? Trata-se de "[...] uma discussão muito complexa. Entretanto, acredita-se que esse componente curricular seja indispensável e necessário na formação 
do discente como cidadão atuante e participativo". (CUSTÓDIO; KLEIN, 2015. p. 71). Para Stigar (2010, p. 3) "A espinha dorsal da problemática do Ensino Religioso está no tratamento dado a esta disciplina, temos uma má interpretação sobre a mesma, oriunda do seu histórico pelo ensino de religião, marcado pelo Catolicismo".

Historicamente o ER esteve presente na formação/educação do povo brasileiro, resquício de uma nação que adotou a religião Católica como oficial do Estado, após a catequização que ocorreu com a chegada dos portugueses, que disseminou o Catolicismo nas colônias, com o intuito de dominação dos habitantes considerados "selvagens". A escola não ficou fora desse processo, já que é considerada, segundo Junqueira (2017, p. 21), "uma instituição cultural construída para transmitir cultura e para socializar saberes produzidos e acumulados no tempo pelos diferentes povos".

$\mathrm{Na}$ atualidade, uma das maiores preocupaçôes da educação escolar brasileira tem sido oferecer aos/às discentes um conhecimento sistematizado e uma profissionalização de qualidade que contribua para seu êxito pleno no mercado de trabalho e na vida social. Entretanto, a grande questáo que fica é se esses objetivos propostos pela educação escolar incluem em sua formação uma cultura da paz, pautada nos valores humanos, no respeito à diversidade, no perdáo e amor ao próximo, ou seja, se incluem temáticas primordiais para uma educação de qualidade que prepara o ser humano para a vida, para o convívio social com o diferente (CUSTÓDIO, 2016, p. 30).

Nesse sentido, a educação escolar deveria incorporar temas sociais do cotidiano dos alunos e alunas, pois os meios de comunicação relatam a todo o momento, casos impactantes sobre as mais diversas formas de violências com aqueles(as) considerados(as) diferentes. A máxima que diz "futebol, política e religião não se discute" já não tem espaço em uma sociedade, em que o ódio entre "torcedores" ultrapassa os muros dos estádios, em situaçôes, onde o esporte transforma-se em uma batalha sem respeito pelo adversário, do mesmo modo no campo político partidário, lugar de disputas sem ética e onde a corrupção atinge os mais altos níveis de desrespeito para com os cidadãos. Manifestar sua religião, crença ou descrença, tornou-se quase que um ato clandestino, devido à intolerância de uma parcela da sociedade que não reconhece a diversidade do país. Neste contexto é imperativo concordar com a afirmativa que diz:

Quebrar paradigmas e superar tabus é uma das missões de uma educação escolar comprometida com a diversidade. A pergunta a ser respondida é se a política educacional brasileira de hoje está baseada em princípios éticos. Vale lembrar neste momento que crianças e adolescentes de hoje são cidadáos e cidadâs do presente e do futuro, pois aquilo que é ensinado e vivido na família, na sociedade em geral e em especial na escola, interfere também na sustentabilidade ambiental planetária, seja no ambiente social, político ou econômico (CUSTÓDIO, 2016, p. 33).

Diante deste cenário de se ter um componente curricular que versa sobre a temática religião, vê-se o ER como componente curricular contribuidor para o processo de aprendizagem e de formaçáo do aluno e da aluna para cidadania, pois se nesta disciplina forem trabalhados temas universais, 
independente de religiōes ou crenças - fraternidade, amor, respeito ao próximo, ética, dentre outros valores que respeitam a vida humana, é possível formar cidadãos com pensamentos críticos. Contudo, o ER por si só, não resolverá toda a problemática de valores éticos, mas acredita-se na sua contribuição, de forma significativa, para a formação humana, onde o respeito é princípio libertador.

A partir destas constataçôes e da inquietação em relação a formação humana pautada nos direitos legais e nos valores humanos, quando ainda na condição estudante de pedagogia, após a disciplina Antropologia Educacional, onde discutíamos a diversidade religiosa e a intolerância com as religióes, e na condição de futuro pedagogo que irá trabalhar tanto no magistério da Educação Infantil, quanto nos anos iniciais do Ensino Fundamental, além de poder assumir a gestão e a coordenação pedagógica em ambientes escolares e não escolares, sabendo que este tema estará em pauta nos trabalhos vindouros, me inquietei com a temática e com a ajuda de minha orientadora, coautora deste trabalho, desenvolvemos a pesquisa que teve como tema "O Ensino Religioso na escola pública: um estudo de caso da prática docente em uma escola em Curralinho/PA", da qual fizemos um recorte para esse trabalho.

A pesquisa baseou-se na abordagem qualitativa, por meio de um estudo de caso, pois, "[...] há uma relação dinâmica entre o mundo real e o sujeito, isto é, um vínculo indissociável entre o mundo objetivo e a subjetividade do sujeito que não pode ser traduzido em números" (KAUARK; MANHÃO; MEDEIROS, 2010, p. 26). Para dar conta dos objetivos buscamos especificadamente: verificar se o currículo adotado pela escola contribui com o respeito e a aceitação das religióes existentes na sociedade; identificar se as práticas pedagógicas desenvolvidas pelos professores contribuem para fomentar o respeito e combater a intolerância religiosa em sala de aula; e discutir a importância do Ensino Religioso na promoção do respeito e na valorização do ser humano.

Para coletar os dados, utilizamos como instrumento a entrevista semiestruturada por ser "desenvolvida de forma mais espontânea, sem que estejam sujeita a um modelo preestabelecido de interrogação" (GIL, 2008, p. 111). O intuito das entrevistas foi para analisar como acontece o planejamento, de onde são retirados os conteúdos e como está organizado o currículo da disciplina ER. Para o professor interlocutor, a entrevista focou em como acontecem as práticas utilizadas em sala de aula. Além da entrevista, realizamos a observação in lócus, que "apresenta como principal vantagem, em relação a outras técnicas, a de que os fatos são percebidos diretamente, sem qualquer intermediação. Desse modo, a subjetividade, que permeia todo o processo de investigação social, tende a ser reduzida" (GIL, 2008, p. 100).

Os dois interlocutores selecionados para pesquisa respectivamente foram um do sexo masculino e um do feminino. No texto para o masculino nos referimos como O professor. Este interlocutor tinha 36 anos (2018), formado em História pela UFPA, trabalhava a disciplina de ER há 3 anos na escola lócus da pesquisa e era responsável em ministrar aulas nas turmas de $5^{\circ}$ ao $9^{\circ}$ ano, trabalhando nos horários da manhã, intermediário e a tarde, segundo ele:

[...] a carga horária de história é muito pequena, [...] entâo passei a trabalhar com Ensino Religioso, e graças a Deus, eu gosto muito e [...] é até melhor do que trabalhar a própria história, pois se tem mais liberdade de fazer a história de uma forma melhor, não só trabalhando aqueles conteúdos que apresenta o planejamento, mas [...] pode-se falar de tudo um pouco, [...] pode falar da história do amor, [...] pode-se trabalhar trechos da bíblia [...] (O PROFESSOR) 
Como sugere a narrativa, o professor gosta de trabalhar a disciplina pela flexibilidade dos conteúdos. De acordo com o seu posicionamento, essa disciplina é muito importante, para “[...] mostrar aos alunos que não existe uma só religião, que ali estamos vivendo em um grupo totalmente miscigenado, com pessoas de "várias raças", cores e conhecimentos, cada um tem um gosto, uma religiáo [...]". Afirma que, a disciplina nas escolas públicas, é importante "[...] para ensinar aos alunos que não importa a questáo da religiáo, o importante é o respeito que você tem por aquele ser humano e o que ele representa para você”.

A interlocutora será identificada nestes escritos como coordenadora pedagógica. É licenciada em Letras e em Pedagogia. Há dois anos trabalhava na coordenaçáo pedagógica da escola em estudo. Em seu entendimento sobre a disciplina, diz que: "quando se trabalha o ER náo é você "puxar" para religião, é tentar diferenciar a religião da disciplina religiosa". Utilizamos o termo interlocutor(a) pois comungamos da concepção de que na pesquisa, as pessoas não são apenas informantes, mas com quem dialogamos, interagimos, ouvimos e fomos ouvidos.

Neste trabalho não temos a pretensão de responder a todos os objetivos da pesquisa, trataremos mais especificamente sobre a prática pedagógica assumida pelo professor do ER, faremos uma breve reflexão sobre o papel da escola na sociedade e a importância de se trabalhar a diversidade religiosa de maneira interdisciplinar no âmbito escolar. Apontaremos um breve histórico legislativo sobre a disciplina de ER e em seguida, apresentaremos as atividades realizadas pelo professor em suas práticas pedagógicas no decorrer das nossas observaçóes em sala de aula, concomitante com as nossas análises.

\section{A PRÁTICA PEDAGÓGICA DO ENSINO RELIGIOSO EM UMA ESCOLA DE ENSINO FUNDAMENTAL NA AMAZÔNIA MARAJOARA}

A sociedade brasileira por sua diversidade torna-se uma sociedade complexa. Essa diversidade está representada em todo território nacional, tornando o Brasil um país plural, cultural, socioeconômico e político. Por essas características, "tornaram-se comuns" os diversos tipos de discriminação e desrespeito para com essa diversificação. $\mathrm{O}$ racismo e a desigualdade de gênero vêm por muitos anos sendo exemplos desses desrespeitos. No entanto, outro tipo de discriminação, que cresce a cada ano é a Intolerância Religiosa, entendida como "toda forma de preconceito, ofensa, ou desqualificação a diferentes crenças e religióes" (REIS, 2017, p. 366).

Em uma sociedade em constantes transformaçóes, no que tange a formação educacional, a escola é uma instituição de grande importância para a formação humana, assim, é preciso reconhecer que: "[...] a escola é um espaço de convivência entre crianças e adolescentes de diferentes origens, de transmissão dos conhecimentos sistematizados sobre o país e o mundo e um dos lugares onde são ensinadas as regras do espaço público" (VALENTE. 2010, p. 30).

As diferenças são representadas entre alunos, alunas, professores e professoras, diferenças de classe social, culturas, etnias, pensamentos e concepçóes diversas. Nessa diversidade que compóem o âmbito escolar, há dois extremos, pois assim como se pode combater ou amenizar as desavenças advindas dessas diferenças, a escola, também pode apresentar exemplos de desrespeito. Ambos os caminhos estão interligados à forma como a instituição visualiza e trabalha a diversidade presente neste espaço de aprendizagem, com vistas as transformaçóes sociais. Nesse cenário,

[...] podem ser ensinadas as regras do espaço público marcadas historicamente pelo desrespeito à diferença: como se fosse possível que a crítica dirigida à sociedade 
permanecesse fora dos muros da escola; como se a desigualdade, a injustiça, os conflitos de classe e de cultura existentes na sociedade, de alguma maneira, fossem neutralizados no contexto escolar, que se tornaria, desse modo, uma realidade a histórica (VALENTE. 2010, p. 30).

O âmbito escolar não é a-histórico, no entanto, a escola ainda reproduz e perpetua atitudes e valores que permanecem enraizados desde os primórdios da formação da sociedade brasileira. $\mathrm{E}$ nesta herança histórica de desrespeito, alguns grupos sociais foram taxados e excluídos, "[...] o índio como selvagem ou preguiçosos; o negro como indolente e bom de samba; a mulata como sensual; [...]. Falam de como essas imagens criadas transitam por nossa mente e por nossas vidas e, nessa medida, acarretam consequências sobre o que é vivido por nós" (GUSMÃO, 2010, p. 86).

Segundo Junqueira (2017, p. 21), a escola já se acostumou a tratar as diferenças como homogêneas para que possa melhor funcionar, assim "[...] a educação aí vinculada cumpriria melhor sua função de condução de grupos em maior escala e menor tempo. Dessa forma, as particularidades culturais das diferentes sociedades e dos grupos minoritários estiveram à margem da educação homogeneizadora".

Se reconhecermos a heterogeneidade do espaço escolar, a interdisciplinaridade ou a pluridisciplinaridade, serão fundamentais para transformar a concepção de uma sociedade homogênea. Se entendermos a escola como uma instituição de formação para cidadania, os conteúdos disciplinares (re)conhecerão as diferenças existentes neste ambiente, para assim, traçar estratégias de combate, respeito e convivência pacífica. Neste contexto, as práticas pedagógicas devem contribuir para discutir essas diferenças. Pois,

[...] trabalhar com a diversidade nas escolas é indispensável, para assegurar a igualdade sem aniquilar as diferenças. Em um país como o nosso, marcado por contraste e desigualdades de recursos, direitos e oportunidades de aprendizagem, de informação de voz ativa, a educaçáo de qualidade para todos torna-se fundamental [...] (JUNQUEIRA, 2017, p. 22).

$\mathrm{Na}$ educação formal, não há uma disciplina específica para esse trabalho, esses temas são interdisciplinares e devem constar na transdiciplinaridade dos currículos, entretanto, alguns assuntos relacionados aos valores humanos, quase sempre aparecem como obrigatórios, nos currículos do Ensino Religioso - ER. Para Custódio (2017) o ER busca compreender e entender o outro. Torna-se de importância ímpar para promover esses debates e levantar questionamentos sobre os assuntos que muitas vezes são deixados em segundo plano em outras disciplinas que não enfrentam o debate sobre a alteridade, o que deixa lacunas na formação humana, uma vez que,

A alteridade revela-se no fato de que o que eu sou e o outro é não se faz de modo linear e único, porém constitui um jogo de imagens múltiplo e diverso. Saber o que eu sou e o que o outro é depende de quem eu sou, do que acredito que sou, com quem vivo e por quê. Depende também das consideraçóes que o outro tem sobre isso, a respeito de si mesmo, pois é nesse processo que cada um se faz pessoa e sujeito, membro de um grupo, de uma cultura de uma sociedade (GUSMÃO, 2010, p. 87).

O fato é que a atitude de colocar-se no lugar do outro, vem se tornando cada dia mais difícil de imaginar em uma sociedade marcada pela desonestidade, primeiro se age para depois pensar nas consequências ou não dos atos, e tomar atitudes éticas - é quase um ato heroico, tamanho são os 
exemplos de desonestidade que cresce e sáo demonstrados em todas as esferas sociais. Convivemos com a corrupção, o xenofobismo, o racismo, o bullyng, as discriminaçôes e intolerâncias religiosa, de gênero, culturais, sociais, entre tantas outras. É preciso promover debates sobre esses assuntos e o ER religioso pode contribuir de forma positiva, pois “[...] não tem mais a ver com expansão de igrejas nem com a educação religiosa, mas com a formação cidadã” (ARAGÃO; SOUZA, 2017, p. 147). Não se trata de gostar, e sim de respeitar o próximo, sendo ele adepto de uma religião, ou não, de crença ou descrença no sobrenatural.

Não é por acaso fazer referência aos sem religião, pois em um trabalho que se dispóem a discutir a diversidade, não se pode deixar de citar aqueles que são minorias, aqueles que não creem no transcendental, no divino. No Brasil e no mundo, muitos fazem parte de grupos que não são adeptos a religióes, entre eles, desconhecidos, autores e intelectuais famosos, como: Richard Dawkins, autor da obra, Deus, um Delírio (2006), o físico teórico Inglês falecido em 2018, Stephen W. Hawking, o brasileiro Eugênio Bucci, que publicou textos como: I belong to... pelo amor de Deus (2001), e o ateísmo como direito (2001). Entre tantos outros, a exemplo de Leandro Karnal, historiador brasileiro assumidamente ateu com grande conhecimento religioso, e como alguns livros que versam sobre a temática.

Destacamos aqui, a obra recentemente lançada no Brasil com o título "Crer ou não crer: Uma conversa sem rodeios entre um historiador ateu e um padre católico” (2017), nesta, edição, Karnal faz uma conversa interessante com o religioso padre Fabio de Melo, mostrando assim, um exemplo, de que um diálogo pacífico de "opostos" é possível. A obra conta com o prefácio de Mario Sérgio Cortella, que avalia dizendo que: "ainda bem que Padre Fábio e Karnal não denotam arrependimento algum pelas crenças e descrenças que suportam; assumem com perspicácia aquilo em que creem e defendem com elegância aquilo de que descreem" (MELO; KARNAL, 2017, 12). Nas palavras de um padre,

Ateus são homens e mulheres que náo viram sentido nas crenças religiosas. Mas
nem por isso estáo dispensados de viver a busca que pode torná-los pessoas
melhores. Antes de sermos crentes ou ateus, somos humanos. Padecemos dos
mesmos conflitos e nos alegramos pelas mesmas causas [...]. O nosso problema
náo é a falta de Deus. Enfrentamos é a falta de valores humanos, de educaçáo, de
conhecimento, de preparo, de solidariedade, de tolerância (MELO; KARNAL,
2017, p. 81).

A afirmativa apresenta alguns conceitos importantes para a vivência social, no entanto, o que se observa é uma sociedade que sofre uma crise de identidade, há uma distorção de valores e crenças. Buscar o diálogo é relevante em busca do respeito. Neste contexto, a escola pode e deve contribuir satisfatoriamente nas disciplinas já tradicionais como português, história, geografia, matemática, ..., e mais ainda na de ER. Essa disciplina é um fértil campo de debates e no decorrer dos tempos apresentou diferentes concepçôes. Segundo Holanda (2017, p. 68), sua inserção esteve presente nas diferentes épocas, e foi expressa nas legislaçôes "com inúmeras questôes em meio às concepçóes epistemológicas e suas relaçôes de natureza pedagógica como componente curricular das escolas públicas". Resumindo esse histórico a autora mostra que:

[...] do período de 1500 a 1800, o ER foi compreendido como ensino da religiáo, em cumprimento dos acordos entre a Igreja Católica e o monarca de Portugal, em decorrência do regime do padroado. [...] de 1900 a 1930, [...] passou por inúmeros questionamentos e, em busca de suas definiçôes decorrentes 
do parágrafo $6^{\circ}$ do artigo 72 da constituiçáo da república dos Estados Unidos do Brasil, promulgada em 1891, estabelecia: "será leigo o ensino ministrado nos estabelecimentos públicos". Esse dispositivo deu origem aos maiores debates da história do ER no Brasil. [...] entre 1934 a 1945, o ER foi admitido em caráter facultativo após amplas discussões entre os favoráveis e os contrários a esse ensino. $\mathrm{Na}$ constituição da república de 1934, o Art. 153 pretendeu salvaguardar o princípio da liberdade religiosa com a expressão "será de matricula facultativa", porém, ministrado a partir dos princípios da confissão religiosa de cada aluno e aluna, portanto na forma confessional, devendo a participação dos alunos e alunas nessas aulas ser manifestada pelos pais ou responsáveis, mas "constituirá matéria dos horários nas escolas públicas primarias, secundárias profissionais e normais. [...] Na constituição de 1937, no Art. 133, o ER perdeu a obrigatoriedade pelo que ficou expresso "Não poderá, porém, constituir objetos de obrigação dos mestres ou professores, nem de frequência compulsória por parte dos alunos". E a constituição de 1946 no Art. 168 retomou os princípios da constituiçáo de 1934 com a seguinte redaçáo: "O ER constitui disciplina dos horários das escolas oficiais, é de matricula facultativa e será ministrada de acordo com a confissão religiosa do aluno, manifestada por ele, se for capaz, ou pelo representante legal (HOLANDA, 2017, p. 68-69).

Após esse percurso histórico legislativo, o ER chega a Constituição Federal - CF de 1988, expresso da seguinte forma no "Art. 210. $\$ 1^{\circ} \mathrm{O}$ ensino religioso, de matrícula facultativa, constituirá disciplina dos horários normais das escolas públicas de ensino fundamental" (BRASIL, 1988, p. 161).

Em 1990, de acordo com esse autor, iniciam-se mudanças significativas nas políticas públicas educacionais, dentre elas uma das mais importantes, "a nova Lei de Diretrizes e Bases da Educação LDB 9394/96 com o propósito de difundir os valores fundamentais ao interesse social, aos direitos e deveres das pessoas cidadãs, de respeito ao bem comum e à ordem democrática com o intuito de unificar e garantir a educação nacional valorizando as diferenças culturais e regionais (HOLANDA, 2017, p. 71). Entretanto, em seu Art. 33 a LDB 9394/96, assim fixava: “[...] o Ensino Religioso, de matrícula facultativa constitui disciplina dos horários normais das escolas públicas de ensino fundamental sendo oferecido, sem ônus para os cofres públicos, de acordo com as preferências manifestadas pelos alunos ou por seus responsáveis [...]".

A inserção da expressão "sem ônus para os cofres públicos", fez com que acontecessem mobilizaçôes por parte da categoria docente, entidades instituiçôes de ensino superior, secretarias de educação, com a expectativa de anular a expressão contida no documento (HOLANDA, 2017). Em meio a discussóes sobre a nova Lei de Diretrizes e Bases da Educação Nacional - LDB n ${ }^{\circ}$ 9394/96, projetos foram encaminhados ao senado com intuito de mudanças. Atualmente, o ER está assim disposto nesta Lei.

Art. 33 - O ensino religioso, de matrícula facultativa, é parte integrante da formação básica do cidadão e constitui disciplina dos horários normais das escolas públicas de ensino fundamental, assegurado o respeito à diversidade cultural religiosa do Brasil, vedadas quaisquer formas de proselitismo.

$\$ 1^{\circ}$ Os sistemas de ensino regulamentarão os procedimentos para a definição dos conteúdos do ensino religioso e estabelecerão as normas para a habilitação e admissão dos professores. 
$\$ 2^{\circ}$ Os sistemas de ensino ouviráo entidade civil, constituída pelas diferentes denominaçóes religiosas, para a definiçấo dos conteúdos do ensino religioso (BRASIL, LDB, 9394/96).

Outras discussôes surgiram a respeito do caráter facultativo e proselitista na disciplina, entendendo esses termos como a não obrigatoriedade de matrícula e a não catequização ou doutrinação em sala de aula. Recentemente, outro fator chama atenção para o ER, o Supremo Tribunal Federal (STF);

[...] julgou improcedente a Ação Direta de Inconstitucionalidade (ADI) 4439 na qual a Procuradoria-Geral da República (PGR) questionava o modelo de ensino religioso nas escolas da rede pública de ensino do país. Por maioria dos votos $(6 \mathrm{x}$ 5), os ministros entenderam que o ensino religioso nas escolas públicas brasileiras pode ter natureza confessional, ou seja, vinculado às diversas religiōes (PORTAL STF, 27 Set. 2017).

Ao votar, a então presidente do STF, ministra Carmen Lúcia, se justificou dizendo: "A laicidade do Estado brasileiro não impediu o reconhecimento de que a liberdade religiosa impôs deveres ao Estado, um dos quais a oferta de ensino religioso com a facultatividade de opção por ele". "De acordo com ela, todos estão de acordo com a condição do Estado laico do Brasil, a tolerância religiosa, bem como a importância fundamental às liberdades de crença, expressão e manifestação de ideias" (PORTAL STF, 27 Out. 2017). Agora então, as escolas podem oferecer um ensino religioso confessional, ou seja, pode voltar o foco para uma religiáo especifica desde que garanta a facultatividade expressa nos documentos; dessa forma, outros debates se iniciam a respeito da disciplina. No entanto há de se concordar com a afirmativa de Filho (2017), de que;

Não faz sentido uma batalha jurídica, confessional ou estatal sobre a presença do ER na escola contemporânea. O que se precisa é que, no processo de aprender no ensino fundamental, alteridades se fortaleçam, vivencias sejam significativas, intolerâncias sejam destruídas, e o que vigore seja o ensino crítico e criativo de uma área fundamental para o nosso tempo: o ER (FILHO, 2017, p. 233).

Diante de todos os marcos regulatórios, debates no meio social em nível nacional, não poderíamos deixar de fazer o nosso papel de cidadáos ativos, nos envolver dentro do processo educacional do qual estamos inseridos. Foi assim que, desde as primeiras ideias de trabalhar com este tema, houve um longo processo para de fato iniciar a pesquisa. A autorização junto à direção da escola para entrarmos em contato com as coordenadoras pedagógicas e professores para as assinaturas dos termos de livre consentimento à participação na pesquisa e nas observaçóes nas suas aulas na disciplina de Ensino Religioso.

Na Secretaria Municipal de Educação (SEMED) do município, após algumas tentativas, foi cedido o Planejamento Curricular construído no ano de 2016, em vigor em 2018. Em meio as dificuldades de náo contar com o apoio na pesquisa, optamos por entrevistar apenas uma das coordenadoras. No período da pesquisa, havia dois professores da disciplina de ER na instituição. Inicialmente o acompanhamento seria com ambos, no entanto, por conta das mesmas dificuldades, acrescentando a incompatibilidade com o horário das aulas, fez-se necessário optar por apenas um deles, assim, acompanhamos aquele que na lotação possuía o maior número de turmas. Embora o professor trabalhasse de $5^{\circ}$ ao $9^{\circ}$ ano, delimitamos o nosso foco para os $6^{\circ}$ e $7^{\circ}$ anos do ensino fundamental em horários e turmas diferenciadas. A convite do professor também acompanhamos 
uma aula na turma de $9^{\circ}$ ano do turno da manhá, pois era uma atividade especial, os alunos e alunas iriam apresentar seminário (aulinha), e o professor avaliou como importante a nossa presença neste momento de socialização das atividades da disciplina.

Para a nossa pesquisa, também se fazia importante esse momento, uma vez que conhecer o trabalho do professor nos ajudaria futuramente, com base nas análises, produzir coletivamente, outras práticas a partir da avaliação do que se tem enquanto metodologia e conteúdo curricular para o Ensino Religioso.

Diante da necessidade de conhecer como se produz o planejamento da disciplina ER na Escola, entrevistamos a coordenadora pedagógica e perguntamos como acontece esse processo, pois de acordo com Vasconcellos (2007) o planejamento é algo que deve ser entendido no seu sentido integral, não se trata apenas de antecipar uma ação e agir de acordo com o previsto. Dessa forma, compreendemos que o planejamento deve ocorrer, durante e depois de qualquer ação e construído de maneira coletiva.

Segundo a coordenadora entrevistada, o planejamento acontece no início de cada ano, quando a escola promove a semana pedagógica, que é o período que a coordenação reúne com os professores e professoras, e é no decorrer dessa semana que se faz o planejamento de todas as disciplinas, incluindo o ER.

[...] quando se fala em ER, a palavra não é dificuldade, é a maneira de entender a concepção de cada um, pois cada um tem pensamento diferente, mas eles (os professores) entram em um consenso, criam seus planejamentos. Claro que cada um com uma ideia diferente um do outro. No entanto, obtém resultados. [...] Quando estamos na formação da semana, sempre tem aquela discussão, até porque quando se fala em religiáo, tem a questáo de não concordância com o que o outro professor está fazendo [...] (COORDENADORA, 2018).

De acordo com a fala da coordenadora, inferimos que cada professor(a) tem autonomia para fazer o planejamento da disciplina que irá ministrar, e ao que indica, não há um planejamento coletivo, ele é feito de forma diferenciada por cada professor(a). É o que fica implícito na afirmativa da interlocutora ao dizer que "não há concordância com o que o outro professor está fazendo". Essa postura sugere que a escola não tem uma definição de como deve ser trabalhado o ER na instituição e nem na escolha do conteúdo curricular do(a) professor(a), sendo assim, aulas que a coordenadora define como "mistura muito a religiâo".

Essa "mistura" mostrou-se bastante presente nas observações in lócus. No entanto, o que mais nos chamou a atenção, foi a preferência dada a uma religião, mostrando no "planejamento" a opção religiosa do docente, diferente do que se busca no ER que é que se apresente as religiôes de forma horizontal, sem exaltar ou diminuir quaisquer que sejam, o foco deve ser o fenômeno religioso e não religioso, A disciplina de ER deve conduzir alunos e alunas em uma perspectiva de:

[...] contribuir com a formação geral da pessoa cidadã, em um exercício de ciência a ser feito com os estudantes sobre as religiosidades e as espiritualidades em suas expressóes simbólicas e valorativas. Trata-se de uma educaçáo "sobre" a religião e "da" espiritualidade, que difere da educação "para" a prática religiosa, que compete às denominaçôes religiosas (ARAGÃO; SOUZA, 2017, p. 151-152).

Não está em jogo se é certo ou errado a doutrinação, o ensino catequético, a educação "para" prática religiosa, entretanto, o que se discute é a liberdade de crença, nesse caso, as pessoas são livres para ensinar, desde que sejam em locais específicos para esses fins. $\mathrm{Na}$ escola, a disciplina 
tem a responsabilidade "[...] de oportunizar o acesso aos saberes e conhecimentos produzidos pelas diferentes culturas e cosmovisões religiosas e pós ou não religiosas, enquanto patrimônios culturais da humanidade" (ARAGÃO; SOUZA, 2017, p. 150). E neste sentido o planejamento torna-se essencial à medida que respeite a produção cultural e religiosa da comunidade.

No que diz respeito ao planejamento da disciplina, também entrevistamos o professor, para compreender como ele participa deste processo. Assim ele afirma.

\section{[...] náo deixo muito o planejamento da SEMED me comprometer, pois muitas vezes, eles criam um conteúdo que nem se está falando da sociedade. De repente está acontecendo uma coisa aqui, tão visível na tua presença [...] no teu mundo, na tua realidade, e você esquece por ter que seguir um processo burocrático, um documento vindo da secretaria. [...] Eles não pensam na realidade do aluno, então, deixo o planejamento flexível, com espaços, lacunas para serem preenchidas de acordo com a necessidade da disciplina e principalmente do aluno (O PROFESSOR, 2018).}

De acordo com as narrativas, observou-se que, coletividade no planejamento da disciplina não é uma realidade. Além disso, o cenário que se apresenta é de divergências entre coordenação e professores da disciplina, dessa forma, o planejamento se individualiza e tem impacto na prática em sala de aula. Diante do exposto, é importante refletir que "para gerar aprendizagem nos estudos, o professor e a professora de ER precisam realizar projetos de parceria e integraçáo com outros docentes que estejam disponíveis a realizar outras práticas [...]” (FILHO, 2017, p. 237). A educação não se dá de forma individualizada, o planejamento deve se fazer coletivamente a fim de se ter um leque de oportunidades de aprendizagem em uma perspectiva interdisciplinar. Do contrário, o objetivo principal que se almeja à educação pública jamais será realidade.

Sobre os conteúdos, o professor afirmou que "procura buscar através do Google play e de livros que vai comprando, faz pesquisas, mas também, foca muito na "questão" da bíblia”. Diz que vai pegando sempre uma experiência na internet, uma experiência na bíblia. A fala da Coordenadora confirma as palavras do Professor, porém, também afirma que havia livros didáticos da disciplina na biblioteca, ainda que em pouca quantidade. Dessa forma questionamos: Será possível atingir os objetivos da Base Nacional Comum Curricular (BNCC) para a disciplina? já que "na segunda etapa, que vislumbra os anos finais correspondentes ao $6^{\circ}$ ao $9^{\circ}$ ano, a BNCC aponta mais quatro objetivos gerais a serem atendidos, a saber" (LINS; CRUZ, 2017, p. 149).

Analisar saberes, experiências e conhecimentos relacionados ao religioso e não religioso enquanto substratos culturais [...]. Construir significados, experiências e atitudes de valorização e respeito à diversidade cultural religiosa [...]. Compreender fatores que levem à demarcação de diferentes e diferenças em nossa sociedade [...]. Identificar posicionamentos e atitudes que permitam salvaguardar a liberdade de consciência e de crença [...].

Em relação aos acompanhamentos/observaçóes realizados em sala de aula, a recepção por parte do professor e dos alunos foi positiva para a continuidade dos estudos. O Professor era bastante comunicativo e apresentava uma boa relação com os discentes. Utilizava-se de algumas citaçóes bíblicas em suas aulas. Neste sentido, era inegável o domínio do professor sobre os capítulos e versículos do livro sagrado cristáo, pela forma como apresentava na íntegra as passagens bíblicas. 
Fazendo claramente referência ou opção por uma religiáo, o professor conduzia boa parte de seus discursos firmando-se na Bíblia Cristá, aceito normalmente pelos alunos e alunas. Nesse contexto precisamos refletir, pois o ER deve;

[...] tratar pedagogicamente do conhecimento espiritual que existe entre e para além de todas as tradiçóes místicas, religiosas e não religiosas, devendo tematizar seus conteúdos simbólicos, nos espaços e tempos sagrado, bem como os valores humanos que as espiritualidades resguardam. Trata-se, entáo de comparar criticamente e interpretar os fatos - também religiosos - nos seus contextos históricos. Em busca de significados mais profundos para esse patrimônio cultural da humanidade que são suas espiritualidades religiosas e atitudes filosóficas (ARAGÂO, 2017, p. 17).

Assim sendo, ensinar com base na bíblia cristã torna-se um equívoco pedagógico, não que nesta prática não tenham sido discutidos temas relacionados ao que afirma Aragão (2017) feita pelo autor. Prender-se nas próprias convicçóes inviabiliza o conhecimento do desconhecido que vai muita além das palavras e do que as pessoas acreditam. Para Junior e Silveira (2017, p. 167) o objetivo central do ER "como campo de aplicação das Ciências da Religião, ou Ciência da Religião, é mostrar a existência e importância das múltiplas identidades culturais e religiosas como fundamentais para a existência e a realização ética de diversos e diferentes grupos sociais".

A formação acadêmica do professor é em história - licenciatura, e sua prática demonstrou um grande domínio dessa área do conhecimento - datas, fatos e personalidades eram utilizados como um recurso para a compressão dos assuntos. Ele fez importantes análises da sociedade e do ser humano de maneira muito crítica e filosófica, mesmo que em determinados momentos com um vocabulário de difícil entendimento para aqueles alunos e alunas que ainda se encontram no ensino fundamental. A preocupação ficou em saber, todos estavam compreendendo as explicaçóes dadas por ele?

Os acompanhamentos das aulas iniciaram em novembro 2017, na turma de $6^{\circ}$ ano e encerrou em maio de 2018. As aulas tinham duração de 40 minutos, a metodologia baseava-se em aulas expositivas "dialogadas" e segundo o Professor, essa metodologia é importante, pois “[...] os alunos são muito voltados para a questão de uma sociedade "grafocêntrica", gostam mais de escrever. [...] Estão acostumados só escrever, esqueceram que tem direito de expressão".

Compartilhamos do pensamento do professor, de que o diálogo é um caminho a ser trilhado para se alcançar o respeito às diferenças. Em relação ao ER, concordamos com Martins Filho (2017) quando afirma que o ER é a disciplina das perguntas e questionamentos, e é importante docentes e discentes entenderem que esses questionamentos são geradores de aprendizagem quando o ser humano busca o conhecimento.

No entanto, discordamos que a palavra seria necessariamente "gostar", e sim, eles estão condicionados a escrever, porém, não podemos dizer que eles e elas não gostam do diálogo, já que este exige muito mais do que falar e ouvir, "o diálogo verdadeiro é animado por liberdade total, não podendo ser movido por oportunismos táticos. O diálogo não pode exigir nada do outro, senão a disposição de ouvi-lo, compreendê-lo e respeitá-lo" (CUSTÓDIO; KLEIN, 2015. p. 73). De fato, um diálogo tal como expresso por Custódio e Klein, não aconteceu, pois foram raras as vezes que os alunos e alunas participaram de forma ativa nas aulas, mesmo com as insistentes tentativas por parte do professor. 
Metodologicamente, as aulas iniciavam com a oração do Pai-Nosso, todos os presentes eram convidados a ficarem de pés e juntos entoavam a oração seguida de aplausos. Para o Professor, "a oração é muito importante para quem acredita em Deus [...] não se pode orar no vazio, é preciso pensar nos que estão doentes, agradecer mais um dia de vida, e pedir perdáo pelos pecados [...] a oração de quem crer tem poder, de quem não crer é igual pedra, e o Espírito Santo não entra em templo de pedra”, dizia ele. Esse fato por si só já é um campo fértil para discussóes e controvérsias, como mostrou a reportagem do portal G1 BA, postado no dia 23 de fevereiro 2016 com a manchete "Ateu denuncia escola da filha ao MP por causa do 'Pai Nosso' antes de aula" (PORTAL G1 BA, 2016). A reportagem ainda afirma que,

Mesmo sem a obrigação o pai da estudante ainda considera a oração uma imposição religiosa. "O estado é laico, as escolas são um braço do Estado e deveriam também respeitar a laicidade, respeitar a diversidade", defende. Já Lenilda Freitas, que tem dois filhos na escola, concorda com a prática religiosa. "Eu acho normal". "Acho que não prejudica em nada a criança” (PORTAL G1 BA, 2016).

Os dois posicionamentos mostram mais uma vez a complexidade da disciplina, e embora não seja obrigação na escola lócus da pesquisa, a oração foi um ato recorrente nas aulas do Professor. Em meio a isto, "é importante lembrar constantemente que não é função do ER escolar promover conversôes, mas possibilitar o estudo do fato religioso visando a uma educação integral, atingindo as diversas dimensóes da pessoa" (RODRIGUES, 2017, p. 212). E na afirmativa de Filho (2017), o ER é para todos, para os que têm e para os que não têm uma religiáo.

Essa é a representação da prática pedagógica do ER adotado pelo Professor. E contempla o planejamento curricular para a disciplina, disponibilizado pela SEMED, que apresenta assim os objetivos específicos para o primeiro semestre do $6^{\circ}$ ano: "Entender que Deus é único e soberano entre outros deuses. Embora haja quem discorde por questóes pessoais. Apresentar razóes que justifique a existência de Deus por meio da criação de todas as coisas. Entender que todas as virtudes procedem de Deus" (SEMED, PLANO DE CURSO - 60 ano EF/9 ER, 2016).

Esta é referência de uma educação cristá, teocêntrica, onde Deus está no centro das explicaçóes. Em concordância com Custódio e Klein (2015), comungamos do pensamento de que "[...] precisamos entender que os estudantes brasileiros das escolas públicas têm liberdade de crença, como qualquer cidadão brasileiro. Há tradiçóes religiosas que pregam o monoteísmo, outras o politeísmo e as que nem sequer se referem a uma figura divina" (CUSTÓDIO; KLEIN, 2015.p. 75). E ao julgar que esses objetivos são orientados para o $1^{\circ}$ bimestre, que corresponde ao período de início das aulas, infere-se que nesse período o professor ainda náo teve tempo para conhecer o perfil dos seus alunos e alunas, assim, suas convicções religiosas são desconsideradas nas orientaçóes do documento.

Entendemos que ao se referir as "questóes pessoais" para quem não entende "Deus como único soberano", expressas no documento curricular da secretaria municipal de educação, podem vir de encontro ao direito à liberdade de pensamento, garantida no Art. 18 da Declaração Universal dos Direitos Humanos - DUDH.

Art. 18 - Toda pessoa tem direito à liberdade de pensamento, de consciência e de religiấo; este direito implica a liberdade de mudar de religiáo ou de convicçáo, assim como a liberdade de manifestar a religiáo ou convicção, sozinho ou em comum, tanto em público como em privado, pelo ensino, pela prática, pelo culto e pelos ritos. 
Embora a coordenação afirme que não há obrigatoriedade em seguir completamente o que a SEMED orienta, percebemos que de maneira direta e indiretamente os conteúdos curriculares sáo trabalhados em todos os anos $-5^{\circ}$ ao $9^{\circ}$ ano. Os planejamentos curriculares para a disciplina, são semelhantes, diferenciando apenas em suas estruturas, pois ambos têm os mesmos objetivos gerais:

Proporcionar ao aluno o conhecimento de diversas crenças, incentivando a necessidade de respeitá-las. Desenvolver a cidadania e o respeito mútuo. Compreender que a família é a base para a formação de um cidadão responsável e cumpridor de seus deveres. A necessidade de ser solidário e atuante na sociedade (SEMED, PLANO DE CURSO, 2016, p. 1).

Os temas trabalhados no período da pesquisa foram: "Cultura Afro-Brasileira: Religióes Africanas" $6^{\circ}$ ano A1 e A2. Apresentação de seminários (aulinhas), fábulas, ética religiosa: Salmo XXIII, festa de São João Batista - padroeiro católico do município. preconceitos, racismo e homofobia. Por conta dos horários das aulas, muitas vezes, o mesmo tema era trabalhando em turmas diferentes.

Na primeira aula, de acordo com o planejamento curricular da disciplina que se encontrava no $4^{\circ}$ bimestre do ano letivo, os objetivos específicos eram: perceber que o respeito a natureza faz parte do respeito à religião. Relacionar a higiene pessoal e mental com a valorização do corpo. Esses objetivos deveriam nortear os conteúdos a serem trabalhados: Meio Ambiente. Natureza. Paisagens (tipos de paisagens). Higiene pessoal. Higiene mental (SEMED, PLANO DE CURSO, 2016, p. 1), no entanto os objetivos divergiram dos conteúdos apresentados.

Diante desta pluralidade de assuntos na disciplina, concordamos com Oliveira (2017, p. 165) quando diz que "o conhecimento religioso é autônomo e irredutível, mas não é um conhecimento isolado do mundo em que vivemos". O ER pode transitar nos mais diversos saberes, mas o autor adverte que é essencial uma "abordagem interdisciplinar". Nesta abordagem, os conteúdos apresentados no planejamento curricular para o ER do município, podem e devem ser facilmente trabalhados em todos os anos do ensino fundamental, em uma perspectiva de respeito e sensibilização para o bem-estar social, para com o meio ambiente e ao próximo. Com uma metodologia voltada para a realidade sem que necessariamente se "misture" a religião.

Nessa perspectiva, Freeman (2017, p. 195) afirma que dessa forma, a metodologia "será mais apropriada se levar em conta as aspiraçóes da escola, a realidade dos educandos, sem considerar o pressuposto da fé (que resulta na catequese), da religiosidade (que resulta na educação religiosa), mas como o pressuposto pedagógico (que resulta no estudo da religião)". Para isso, voltamos a inferir a importância de um planejamento coletivo que alcance todas as disciplinas, visto que, para Oliveira (2017) são as práticas interdisciplinares que incentivam a experiência para o aprender no campo religioso, sem isso é "impossível avançar".

O professor disse que deixava lacunas a serem preenchidas no planejamento, como exemplo, o trabalho que realizou no dia 20 de novembro, quando se comemora, o dia da consciência negra. Nesse dia o professor trabalhou assuntos de grande importância para a formação pessoal e cidadã dos alunos e alunas - diferentes religiôes e culturas. Historiou sobre o período da escravidão brasileira e a contribuição dos escravos para a formação da sociedade e da religiosidade. Nas palavras dele "sem se prender as orientaçôes da SEMED".

Destacamos a importância do trato com as diferentes religiôes, pois, segundo Reis (2017), em muitas vezes na escola, muitas delas são marcadas pela intolerância. Para este autor, 
[...] não são raras as situaçóes em que o ensino sobre o candomblé e a umbanda não é ministrado a mando do diretor da escola ou por iniciativa do próprio professor ou professora. Quando essas religióes são apresentadas pelas escolas, há ocasiōes em que são associadas como algo demoníaco e, por isso, devem ser combatidas. Há realidades em que os próprios alunos e alunas, justamente com os pais, se recusam a aprender sobre o universo dessa instituição religiosa (REIS, 2017, p. 366-367).

Neste contexto, diferentemente do exposto pelo autor, nas observaçóes realizadas, a aula deste dia foi de fato como é, ou deveria ser o ER nas escolas públicas, já que se sabe que essa disciplina "tem como princípio norteador, de sua abordagem para o processo de ensino aprendizagem o tripé “pergunta, pesquisa e diálogo" (BRASIL, 2016 apud LINS; CRUZ, 2017, p. 144). E o PCER (2018) da instituiçáo, orienta provocar o debate dos assuntos exposto. Houve um momento importante para reflexão e aprendizado, quando se falava de religião de matrizes africanas em uma concepção histórica. Em rara participação dos discentes, uma aluna perguntou ao professor: "Macumba é "pra” fazer o mal? Ou ela também faz o bem?". No questionamento, vemos claramente um reflexo de como essas religióes são vistas por grande parte da sociedade, e confirma-se a afirmativa de Reis (2017) quando observa que, muitas vezes essas religióes são tidas como algo do mal, do demônio.

Um fato que exemplifica muito bem essa afirmação foi exposto pelo $2^{\circ}$ grupo do seminário (aulinhas) na turma de $9^{\circ}$ ano A1. Embora tivesse como tema da apresentaçáo "preconceito racial", a exposição dos(as) aluno(as) lembrou um caso ocorrido no ano de 2015 no Rio de Janeiro, segundo a reportagem da época no portal de notícia G13 tem como título, "Menina vítima de intolerância religiosa diz que vai ser difícil esquecer pedrada"

A garota foi agredida [...] e, segundo a avó, que é mãe de santo, todos estavam vestidos de branco, porque tinham acabado de sair do culto. Eles caminhavam para casa, na Vila da Penha, quando dois homens começaram a insultar o grupo. Um deles jogou uma pedra, que bateu num poste e depois atingiu a menina. "O que chamou a atençáo foi que eles começaram a levantar a Bíblia e a chamar todo mundo de 'diabo', 'vai para o inferno', 'Jesus está voltando”, afirmou a avó da menina, Káthia Marinho (PORTAL G1, 16 de Jun.2015).

Reis (2017) afirma que, esses grupos ou indivíduos que "perseguem" e atacam as pessoas de outras religiôes, sentem-se os "puros", os "escolhidos" e defendem que apenas suas concepçóes religiosas são verdadeiras, corretas. Respeito foi a palavra. Embora o professor náo tomasse o conceito para responder à aluna, questionamento que por sinal poderíamos percorrer um caminho em direçáo ao diálogo sobre bem e o mal, o certo ou errado. Mas não, o professor imediatamente questionou: “Quem está em uma igreja católica ou evangélica só faz o bem?” A aluna respondeu: "não", então o diálogo terminou com outro questionamento por parte do professor "Respondi sua pergunta?".

O PCER (2018) na instituição, apresenta em quatro momentos a palavra "Bíblia”, assim, no singular, 03 delas ( $7^{\circ}$ ano, $8^{\circ}$ ano e $9^{\circ}$ ano), orienta como recursos para trabalhar os temas, ainda no $9^{\circ}$ ano também, orienta como um dos três objetivos específicos para o $1^{\circ}$ bimestre do ensino

3 Disponível em: http://g1.globo.com/rio-de-janeiro/noticia/2015/06/menina-vitima-de-intolerancia-religiosa-diz-que-vai-ser-dificil-esquecer-pedrada.html postado em: 16/06/2015 12h56. Acessado em: 29 de Junho de 2018 
fundamental, lê-se - "Estabelecer a diferença entre o amor divino e material a luz da bíblia" (PCER, 2018, p. 6).

Os documentos disponibilizados para esta pesquisa, não fazem referência a outros livros sagrados. O PCER (2018) orienta como recursos e estratégias de $5^{\circ}$ ao $9^{\circ}$ ano, textos, dicionários, livros bíblicos e "dramatização que envolva fatos bíblicos". Entre outros recursos, especificadamente para o $7^{\circ}$ ano, "revistas, bíblia, cartazes, fita de vídeo, textos, vídeos, cartazes, textos ilustrados, vestimentas típicas, comidas, tinta, pincéis, livros. Visita de Pastores, Padres, Freiras, catequistas" (PCER, 2018, p. 5).

O Professor diz que se utiliza bastante dos ensinamentos bíblicos com recursos em sala de aula junto com experiências de vida e assuntos da internet. Esse fato confirmou-se nos acompanhamentos/observaçóes, dos quais destacamos dois momentos, na turma de $6^{\circ}$ ano (manhã) e $6^{\circ}$ ano (tarde). O tema foi apresentado como "Ética Religiosa: Salmo XXIII" (O senhor é meu pastor: nada me faltará), escrito no quadro após o professor perguntar para os alunos e alunas se conheciam o tema. O título da aula "Ética Religiosa" não se mostrou na prática, a aula inteiramente foi focada no Salmo de Davi, constantemente citado pelo professor. Nas aulas, ainda surgiram explicaçôes sobre "parábola do bom samaritano narrada por Lucas 10 (p. 1435), Apocalipse 20, que apresentam os livros "os mil anos" "o julgamento final” "A derrota de satanás" (BÍBLIA, 2012, p. 1743).

O uso dos livros didáticos com conteúdos descontextualizados, usados equivocadamente em sala de aula, também geram discussóes. Para a disciplina de ER, Custódio (2017, p. 223 apud Kluck, 2017) afirmam, "[...] muitas obras professam doutrinas religiosas especificas, discriminam comportamentos, ideias e reforçam a intolerância” e se buscamos um ER que trabalhe a diversidade social, religiosa e não religiosa, a utilização de textos do livro sagrado de uma religião especifica não parece ser uma forma de promover um debate multireligioso. Neste contexto, Custódio (2017) apresenta propostas para os professores(as):

b) o educador ou a educadora precisa atentar para o respeito às diferentes expressóes religiosas ou não do sujeito em sala de aula e na sociedade em geral, bem como para o reconhecimento das diferentes manifestaçôes do sagrado; c) o educador ou a educadora precisa estar atento às políticas educacionais que estão sendo discutidas no espaço escolar, bem como suas práticas pedagógicas adotadas estão condizentes como a realidade e com o cotidiano da escola, entre outras questōes (CUSTÓDIO, 2017, p. 218-219).

As propostas citadas são importantes, pois orientam docentes que precisam estar constantemente em busca de novos conhecimentos. Conhecer a diversidade social e as leis que orientam a educação são de extrema importância para o profissional da educação. Para o ER, é preciso atentar para as mais diversas manifestaçóes religiosas na sociedade, na escola, e por consequência em sala de aula. Assim, os fenômenos religiosos devem ser apresentados aos alunos e alunas de maneira igualitária em busca do respeito.

É de conhecimento público, que o Art. 33 da LDB 9394/96 veda quaisquer formas de proselitismo no ER. Reis (2017) analisa que acontecem várias formas de intolerância de diversas maneiras no âmbito escolar. Porém, para Andrade (2009) o brasileiro é marcantemente religioso, e isso se expressa no cotidiano social de cada um, "se entendermos a religiosidade como sendo uma autêntica dimensão humana, onde essa necessidade seja a plena realização [...]” (CUSTÓDIO; KLEIN, 2015. p. 77).

O docente, como um membro dessa sociedade de dicotomias e contradiçôes, também manifesta 
suas concepçôes filosóficas, sociológicas, religiosas ou não religiosas. Nesse sentido, Custódio e Klein (2015) nos questionam se realmente será possível um ER sem proselitismo.

Há de considerar a dificuldade de permanecer-se "neutro" nas questôes religiosas, futebolística e políticas partidárias, cada um(a) tem suas concepçóes de certo e errado, do bem e mal, de melhor e pior, essas concepçóes os movem no dia a dia nos comportamentos sociais. Na escola, docentes e discentes representam uma sociedade diversificada, portanto não se deve "fugir", silenciar esses temas, é preciso levantar debates que busquem o entendimento e o respeito. Para isso, as próprias concepções não devem ser apresentadas como verdade absoluta por parte do docente.

As observaçóes, na turma de $7^{\circ}$ Ano, o tema do seminário (aulinha) foi fábulas. Para o Professor, essas narrativas são importantes, pois "elas possuem sempre uma mensagem" “[...] as fábulas de Esopo, de Jean de La Fontaine foram trabalhadas com o objetivo de proporcionar conhecimento, que possamos alcançar processos favoráveis, e venha trazer benefícios educativos para os alunos" afirmou o professor. De fato, as apresentaçóes foram bastante interessantes, as fábulas "Raposa e a cegonha" a "Rã é o boi" e "A nova roupa do rei" foram apresentadas por alunos e alunas. Ao final de cada apresentação, o professor fazia suas consideraçóes abordando conceitos como: vaidade, pureza, respeito, aceitação, entre outros.

Sobre o seminário (aulinha) na turma do $9^{\circ}$ ano, a metodologia proporcionou aprendizado, reflexão e emoção. Quando se falou sobre o preconceito racial, um dos alunos relatou a história do pai que náo foi aceito no exército por conta da cor de sua pele. Falou da tristeza que sentiu, e com lagrimas nos olhos o aluno declarou o amor que sente pelo pai, e ainda, que se sente constrangido por "ser de pele clara e o pai de cor escura", afirma que não gosta das "brincadeiras" que acontecem por conta desse fato.

Em outra apresentação, mais histórias, desta vez sobre o preconceito contra pessoas de orientação sexual diferente da considerada, "padrão". Duas realidades se mostraram, a primeira sobre um membro de uma família que sofria muito preconceito, em forma de "brincadeiras" que o machucavam. A outra, sobre o filho "que namorava um menino" descoberto pelo pai, e foi mandado para o meio rural para não manter contato com o namorado. Um dos grupos trouxe a frase "náo é estranho ser gay, estranho é ser homofóbico" e outro "Perante a Deus todos nós somos iguais". Em todos os trabalhos apresentados, o conceito respeito ao próximo foi lembrado pelo(a)s aluno(a)s, e ao final de cada apresentação reforçada pelo professor. São fatos que ainda acontecem com frequência em pleno século XXI, quando já deveríamos ter ultrapassado esses e outros tipos de preconceitos.

Compartilhamos do pensamento que "em tal conjuntura ou cenário, o ER, lidando como o pluralismo e dentro dele como o tema transversal da orientação sexual e do gênero, pode criar possibilidades de diálogo entre os diferentes" (OLIVEIRA, A. 2017, p. 381). Entretanto há de se considerar que neste caso a religiáo tem forte influência, as concepçóes aprendidas na educação religiosa familiar por alunos e alunas pode causar algumas resistências para que esse diálogo aconteça, a exemplo foi um comentário que surgiu no decorrer das apresentaçóes "meu pai disse que aos olhos de Deus, isso é errado". Ao final, o Professor explica que não importa a orientação sexual das pessoas, e se "eu acho que é errado" o respeito deve ser mantido. O professor finalizou a aula com o poema "Preconceitos" de Victor Motta.

O professor trabalhava muito a autoestima dos(as) alunos e alunas, falava sobre a dedicação e o foco nos estudos, prezava pela atenção de cada um, dizia: "O importante não é o professor, e sim, o que ele tem para ensinar. $\mathrm{O}$ conhecimento”. Embora demostrasse sua opção religiosa, em nenhum momento foi intolerante com as demais religiôes. Os valores humanos eram constantemente temas das explicaçôes. Paz, amor, respeito, ética, gratidão, doação, cooperação e tantos outros, foram 
explorados de maneira consistente, na maioria das vezes com ensinamentos bíblicos. Os problemas sociais nacionais e municipais, ou temas com maior relevância, tinham sempre espaço para análise antes das oraçóes de todas as aulas.

\section{CONSIDERAÇÕES FINAIS}

Diante dos estudos realizados consideramos que o currículo apresentado pela escola para o $\mathrm{ER}$, de forma direta e indiretamente traz orientaçôes de uma religiosidade cristã, entretanto, não faz críticas aos não religiosos e nem se posiciona curricularmente em relação a elas, deixando-as como inexistentes, não atendendo os direitos de liberdade de expressão dos alunos e alunas que têm pensamentos diferentes do que é proposto pela secretaria de educação, pela escola e trabalhado pelo professor.

Quanto as práticas pedagógicas, ficou explícito nas falas do professor e nas observaçóes em sala de aula, que no período estudado, a metodologia das aulas do ER, oscilava entre um ensino crítico e libertador, pois promovia, incentivava o respeito e a tolerância religiosa, de gênero e racial; por outro lado, um ensino que se aproximava à doutrinação, o que ia de encontro as orientaçóes para a disciplina. Embora o conhecimento demonstrado sobre as leis que regem o ER e a diversidade religiosa existente na sociedade, a prática do professor, optava por manifestar suas convicçóes religiosas.

Os conteúdos utilizados nas aulas foram basicamente textos bíblicos, contradizendo o que estudos da área idealizam do que é ou do que deveria ser o ER nas escolas públicas e o que propóe a legislação educacional - apresentar os fenômenos religiosos como um fator cultural e social. Que permita os questionamentos e os diálogos inter-religiosos em uma perspectiva de formação e valorização do ser humano. Que tenha como princípio o respeito, a tolerância para com as diferenças e a convivência pacífica entre crentes e descrentes em um ser ou seres divinos que movem as religióes por todo o mundo.

Por fim, não se pode afirmar que essa é uma ação assumida individualmente pelo professor no trato com o ER, uma vez que o documento oficial da Secretaria de Educação do município em estudo, lhe orienta trabalhar de forma que uma religião, ou que o cristianismo seja mola propulsora dos debates, já que ele está presente de diversas maneiras no currículo desta disciplina e se não há outra orientação, como cobrar somente do professor? Certamente ele é apenas mais um dentre tantos nesse arquipélago, quiçá, nesse país, que não tem formação para trabalhar essa disciplina e que trabalha por "gostar" dos conteúdos, conforme ele afirmou, por ser mais "fácil” do que outros de outras disciplinas, ou quem sabe, para ampliar a sua carga horária, já que a (des)valorização profissional não garante um salário digno a essa classe.

Dessa forma, entendemos por meio deste trabalho, que a responsabilidade de assumir práticas pedagógicas para um ensino religioso inclusivo, que respeite todas as religiôes, crenças e não crenças, no sentido de garantir a laicidade no ensino, deve ser de todos e todas que fazem e produzem a educação formal deste país. 


\section{REFERÊNCIAS}

ANDRADE, Maristela Oliveira de. A Religiosidade Brasileira: o pluralismo religioso, a diversidade de crenças e o processo sincrético. CAOS - Revista Eletrônica de Ciências Sociais. 2009.

ARAGÃO. G. de Souza; SOUZA. M. F. C. Modelos de Ensino religioso. In: JUNQUEIRA, Sérgio. R. A.; BRANDENBURG, Laude E. e KLEIN, Remí. (Orgs.). Compêndio do Ensino Religioso. São Leopoldo: Vozes, 2017. p. 147-156.

BÍBLIA SAGRADA. Nova tradução na linguagem de hoje. Sociedade bíblica do Brasil. Barueri, São Paulo, 2012.

BRASIL. Constituição da República Federativa do Brasil. Brasília, DF, Senado, 1988.

BRASIL. Lei de Diretrizes e Bases da Educaçáo Nacional. Lei no 9.394, 20 de dezembro de 1996. Disponível em: http://www2.senado.leg.br/bdsf/bitstream/handle/id/529732/lei de diretrizes e bases 1ed.pdf Acessado em 14/03/2018. Acessado em 14 de mar. 2018.

CURRALINHO-PA, Secretaria Municipal de Educação (SEMED). Plano de curso de Ensino Religioso - PCER 60 ano EF/9 ER, 2018.

CUSTÓDIO, E. S. Cultura de Paz, Perdão e Valores Humanos. Protestantismo em Revista | São Leopoldo | v. 40 | p. 29-38 | jan./abr. 2016 Disponível em: http://periodicos.est.edu.br/index.php/nepp Acessado em: 01 de mar. 2018.

CUSTÓDIO, E. S.; KLEIN, R. Ensino Religioso e diálogo inter-religioso nas escolas Públicas. Protestantismo em Revista | São Leopoldo | v. 36 | p. 64-79 | jan./abr. 2015 Disponível em: < http://periodicos.est.edu.br/ index.php/nepp> acessado em: 01 de mar. 2018.

CUSTÓDIO, E. Serrão. Ensino Religioso na escola Introdução à Parte III. In: JUNQUEIRA, Sérgio. R. A.; BRANDENBURG, Laude E. e KLEIN, Remí. (Orgs.). Compêndio do Ensino Religioso. Sáo Leopoldo: Vozes, 2017. p. 217-224.

FILHO. Lourival José M. Aprendizagem Básicas no Ensino Religioso nos anos iniciais e finais do ensino fundamental. In: JUNQUEIRA, Sérgio. R. A.; BRANDENBURG, Laude E. e KLEIN, Remí. (Orgs.). Compêndio do Ensino Religioso. São Leopoldo: Vozes, 2017. p. 231 - 238.

FREEMAN, Valeska. Interdisciplinaridade no Ensino Religioso. In: JUNQUEIRA, Sérgio. R. A.; BRANDENBURG, Laude E. e KLEIN, Remí. (Orgs.). Compêndio do Ensino Religioso. São Leopoldo: Vozes, 2017. p.196-201.

GIL, Antônio Carlos. Métodos e técnicas de pesquisa social. 6 ed. São Paulo: Atlas, 2008.

GUSMÃO, Neusa M. M de (Org.). O desafio da diversidade na escola. In: Diversidade cultura e educaçáo: olhares cruzados. 2a ed. Sáo Paulo: Biruta, 2010. 
HOLANDA, Ângela M. R. Ensino Religioso nas legislaçôes. In: JUNQUEIRA, Sérgio. R. A.; BRANDENBURG, Laude E. e KLEIN, Remí. (Orgs.). Compêndio do Ensino Religioso. São Leopoldo: Vozes, 2017. p. 68-81.

JÚNIOR, Manoel R. de M.; SILVEIRA, Emerson J. S. Objeto de estudo. In: JUNQUEIRA, Sérgio. R. A.; BRANDENBURG, Laude E. e KLEIN, Remí. (Orgs.). Compêndio do Ensino Religioso. São Leopoldo: Vozes, 2017. p. 167-180.

JUNQUEIRA, Sérgio. R. A. (Org.). Introdução Geral. In: JUNQUEIRA, Sérgio. R. A.; BRANDENBURG, Laude E. e KLEIN, Remí. (Orgs.). Compêndio do Ensino Religioso. São Leopoldo: Vozes, 2017. p.21-25. KAUARK. F; MANHÂES. F. Castro; MEDEIROS, C. Henrique. Metodologia da pesquisa: guia prático /, ed. Via Litterarum, Itabuna / Bahia, 2010.

LINS. Eunice S.; CRUZ, Josilene S. Objeto de estudo, objeto e eixos do ensino religioso na base nacional comum curricular. In: JUNQUEIRA, Sérgio. R. A.; BRANDENBURG, Laude E. e KLEIN, Remí. (Orgs.). Compêndio do Ensino Religioso. São Leopoldo: Vozes, 2017. p. 143-147.

MELO, Fábio de. KARNAL, L. Crer ou náo Crer: uma conversa sem rodeios entre um historiador ateu e um padre católico. 1. Ed. - São Paulo: Planeta, 2017.

OLIVEIRA, Aurenéa M. Questôes de Gênero/Orientação sexual e ensino religioso. In: JUNQUEIRA, Sérgio. R. A.; BRANDENBURG, Laude E. e KLEIN, Remí. (Orgs.). Compêndio do Ensino Religioso. São Leopoldo: Vozes, 2017. p. 376-382.

OLIVEIRA, Ednilson T. Conhecimento religioso. In: JUNQUEIRA, Sérgio. R. A.; BRANDENBURG, Laude E. e KLEIN, Remí. (Orgs.). Compêndio do Ensino Religioso. São Leopoldo: Vozes, 2017. p. 156-166.

ONU. Declaração Universal dos Direitos Humanos, 1948, disponível em: http://www.onu.org.br/ img/2014/09/DUDH.pdf. Acessado em: 03 de Março de 2017.

PORTAL DE NOTICIA G1 BA, Ateu denuncia escola da filha a MP por causo do 'Pai Nosso' antes de aula, 2016. Disponível em: http://g1.globo.com/bahia/noticia/2016/02/ateu-denuncia-escola-da-filha-ao-mp-por-causa-do-pai-nosso-antes-de-aula.html. Acessado em: 04 de Março de 2017.

PORTAL DE NOTICIA Supremo Tribunal Federal (STF). STF conclui julgamento sobre ensino religioso nas escolas públicas. Disponível em: http://www.stf.jus.br/portal/cms/verNoticiaDetalhe.asp?idConteudo=357099. Acessado em: Maio de 2017.

REIS, Marcos V. de Freitas. Ensino Religioso e Intolerância Religiosa. In: JUNQUEIRA, Sérgio. R. A.; BRANDENBURG, Laude E. e KLEIN, Remí. (Orgs.). Compêndio do Ensino Religioso. São Leopoldo: Vozes, 2017. p.366-369.

RODRIGUES, Edile Maria F. Desenvolvimento Religioso. In: JUNQUEIRA, Sérgio. R. A.; BRANDENBURG, Laude E. e KLEIN, Remí. (Orgs.). Compêndio do Ensino Religioso. São Leopoldo: Vozes, 2017. p.207-213. 
STIGAR, Robson. A construção do Ensino Religioso na atual LDB. Último Andar [18] - $1^{\circ}$ semestre de 2010.

VALENTE. Ana Lúcia E.F. Conhecimentos antropológicos nos Parâmetros Curriculares Nacionais: Para uma discussão sobre a pluralidade cultural. In: GUSMÂO, Neusa M. M de (Org.) Diversidade cultura e educaçáo: olhares cruzados. 2a ed. São Paulo: Biruta, 2010.

VASCONCELLOS, Celso dos Santos. Planejamento Projeto de Ensino aprendizagem e Projeto PolíticoPedagógico - Elementos metodológicos para elaboração e realização. 17 ed. São Paulo. Libertad Editora. 2007. 